\title{
Direct stimulation of osteoclastogenesis by MIP-1a: evidence obtained from studies using RAW264 cell clone highly responsive to RANKL
}

\author{
Toshiyuki Watanabe ${ }^{1}$, Toshio Kukita ${ }^{1}$, Akiko Kukita $^{2}$, \\ Naohisa Wada ${ }^{1}$, Kazuko Toh ${ }^{1,3}$, Kengo Nagata ${ }^{3}$, \\ Hisayuki Nomiyama ${ }^{4}$ and Tadahiko lijima ${ }^{3}$ \\ ${ }^{1}$ Oral Cellular and Molecular Biology, Division of Oral Biological Sciences, Faculty of Dental Science, Kyushu University, Fukuoka, Fukuoka 812-8582, Japan \\ ${ }^{2}$ Department of Microbiology, Saga Medical School, Saga, Saga 849-0937, Japan \\ ${ }^{3}$ Oral Anatomy and Cell biology, Faculty of Dentistry, Kyushu University, Fukuoka, Fukuoka 812-8582, Japan \\ ${ }^{4}$ Department of Biochemistry, Faculty of Medicine, Kumamoto University, Kumamoto, Kumamoto 860-0811, Japan \\ (Requests for offprints should be addressed to T Kukita; Email: kukitat@dent.kyushu-u.ac.jp)
}

\begin{abstract}
Macrophage inflammatory protein-1 $\alpha$ (MIP-1 $1 \alpha)$ is a member of the CC chemokines. We have previously reported the use of a whole bone marrow culture system to show that MIP-1 $\alpha$ stimulates the formation of osteoclastlike multinucleated cells. Here we use rat bone marrow cells deprived of stromal cells, and clones obtained from murine macrophage-like cell line RAW264 to show that MIP- $1 \alpha$ acts directly on cells in osteoclast lineage. We obtained several types of RAW264 cell clones, one of these clones, designated as RAW264 cell D clone (D clone), showed an extremely high response to receptor activator of NFKB ligand (RANKL) and tumor necrosis factor- $\alpha$ (TNF- $\alpha$ ), while the other clone, RAW264 cell N clone ( $\mathrm{N}$ clone), demonstrated no response to RANKL or TNF- $\alpha$. Although both clones expressed receptor activator NFKB (RANK) before being stimulated for differenti-
\end{abstract}

ation, only the $\mathrm{D}$ clone expressed cathepsin $\mathrm{K}$ when cells were stimulated to differentiate to osteoclasts. MIP- $1 \alpha$ stimulated the formation of mononuclear preosteoclastlike cells from rat bone marrow cells deprived of stromal cells. MIP-1 $\alpha$ also stimulated formation of osteoclast-like multinucleated cells from the D clone, when these cells were stimulated with RANKL and TNF- $\alpha$. These findings provide strong evidence to show that MIP- $1 \alpha$ acts directly on cells in the osteoclast lineage to stimulate osteoclastogenesis. Furthermore, pretreatment of RAW264 cell D clone with MIP-1 $\alpha$ significantly induced adhesion properties of these cells to primary osteoblasts, suggesting a crucial role for MIP- $1 \alpha$ in the regulation of the interaction between osteoclast precursors and osteoblasts in osteoclastogenesis.

Journal of Endocrinology (2004) 180, 193-201

\section{Introduction}

Chemokines, a family of the small cytokines, are known to be chemotactic factors against various types of white blood cells. Each chemokine has four conserved cystein residues and they can be classified into four types: $\mathrm{C}$ chemokines, CC chemokines, CXC chemokines and CXXXC chemokines; the classification depends on the number of amino acids between the first and the second cystein residue. Macrophage inflammatory protein-1 $\alpha$ (MIP-1 $\alpha$ ) (Nakao et al. 1990), a member of the CC chemokines, has chemotactic activity against monocytes, lymphocytes, dendritic cells, eosinophils, and natural killer cells (Cook et al. 1995, Lukacs et al. 1996, Shimada et al. 1998, McDyer et al. 1999, Inngjerdingen et al. 2001). This cytokine was also shown to be involved in the regulation of growth and differentiation of hematopoietic cells (Shiozaki et al. 1992, Broxmeyer et al. 1993). Neote et al. (1993) identified MIP-1 $\alpha$ receptor as a G-protein-coupled receptor with seven transmembrane domains.

Osteoclasts are multinucleated giant cells which resorb bone. These cells are hematopoietic in origin and mononuclear precursors of osteoclasts fuse to each other to form multinucleated osteoclasts. We have previously used in situ hybridization to demonstrate the expression of MIP- $1 \alpha$ in human normal bone tissues (Kukita et al. 1997). We have also used a rat bone marrow culture system to show that MIP-1 $\alpha$ induces the formation of osteoclast-like multinucleated cells (Kukita et al. 1997). Choi et al. (2000) and Han et al. (2001) reported that MIP-1 $\alpha$ is involved in osteoclastogenesis associated with multiple myeloma. However, it remains unclear whether MIP-1 $\alpha$ acts 
directly on cells in the osteoclast lineage or acts indirectly via bone marrow stromal cells.

RAW264 cells are known to have characteristics of murine macrophages with the ability to differentiate into osteoclast-like cells by receptor activator of NFKB ligand (RANKL) stimulation (Hsu et al. 1999). The use of cell lines of osteoclast precursors provides numerous advantages for studies on the mechanism of osteoclast differentiation at a molecular level. Here we isolated novel clones with a highly efficient ability to form osteoclasts from RAW264 cells and examined their ability to respond to MIP-1 $\alpha$. We further examined how MIP-1 $\alpha$ modulated the binding properties of osteoclast precursors to osteoblasts. This study focused on clarifying the direct action of MIP- $1 \alpha$ on cells in the osteoclast lineage.

\section{Materials and Methods}

\section{Materials}

Rats were obtained from SEAC Yoshitomi (Fukuoka, Japan). Original RAW264 cells were obtained from American Type Culture Collection (Rockville, MD, USA), and RAW264.7 cells were provided by Dr Muta, Kyushu University School of Medicine. Culture vessels were from Becton Dickinson Labware (Lincoln Park, NJ, USA) and tartrate-resistant acid phosphatase (TRAP) staining kit was from Sigma-Aldrich. Soluble RANKL and MIP-1 $\alpha$ were obtained from Peprotec Science (London, UK). Tumor necrosis factor $\alpha$ (TNF- $\alpha$ ) was purchased from Roche. Reverse transcriptase and Taq-DNA polymerase were obtained from Takara (Kyoto, Japan).

\section{Animal treatment}

Rats were maintained in accordance with the Guide for the Care and Use of Laboratory Animals at Kyushu University.

\section{Bone marrow cultures for forming mononuclear preosteoclast-like cells}

Bone marrow cells were obtained from the tibia and femur of 4-week-old male Sprague-Dawley rats. Bone marrow stromal cells were depleted by the use of a Sephadex G10 column as described previously (Kukita et al. 1993b). These cells were cultured in 24-multiwell plates $\left(1 \times 10^{6}\right.$ cells/well) for 4 days in $\alpha$-modified Eagle's medium $(\alpha-M E M)$ containing $15 \%$ fetal calf serum (FCS) and $10^{-8} \mathrm{M} 1 \alpha, 25$-dihydroxycholrecarciferol $\left(1 \alpha, 25(\mathrm{OH})_{2} \mathrm{D}_{3}\right)$ and $10 \%(\mathrm{v} / \mathrm{v})$ heat-treated ROS17/2.8-cell-conditioned medium (Kukita et al. 1993a).

Culture conditions for forming osteoclast-like multinucleated cells from RAW264 cells

RAW264 cells were cultured in $\alpha$-MEM containing $10 \%$ FCS $\left(3.5 \times 10^{4}\right.$ cells in $500 \mu \mathrm{l} /$ well for 24 -multiwell culture plates or $6.8 \times 10^{3}$ cells in $150 \mu \mathrm{l} /$ well for 96 multiwell plates) for 3 days in the presence of various concentrations of soluble RANKL and TNF- $\alpha$ with various concentrations of MIP-1 $\alpha$.

\section{Primary culture of osteoblasts and adhesion experiments}

Primary osteoblasts were obtained from calvaria of 2-dayold Sprague-Dawley rats and cultured as described previously (Kukita et al. 1993b). Cells were cultured in $\alpha$-MEM containing 10\% FCS. The cell suspension of the $\mathrm{D}$ clone was seeded on the confluent culture of primary osteoblasts. After 3-6 h incubation at $37^{\circ} \mathrm{C}$, cultures were washed with PBS to remove non-adherent cells and were then stained for TRAP.

\section{Cloning of RAW264 cells}

Before isolating RAW264 cell clones, the culture condition was determined by optimizing the concentrations of cytokines to form a large number of osteoclast-like cells from the original RAW264 cells. Combinations of 20$100 \mathrm{ng} / \mathrm{ml} \mathrm{RANKL}$ and $1 \mathrm{ng} / \mathrm{ml}$ TNF- $\alpha$ provided the most suitable conditions for osteoclastogenesis. The limiting dilution of RAW264 cell suspension was established by use of a standard protocol followed by culture for 1014 days to form colonies. The ability to induce osteoclastogenesis was assessed for each clone by checking the ability to form osteoclast-like cells. Cells from each clone were cultured in the presence of $20 \mathrm{ng} / \mathrm{ml}$ RANKL and $1 \mathrm{ng} / \mathrm{ml}$ TNF- $\alpha$ for 3 days, followed by staining for TRAP. Cloning of the cells was repeated twice for each clone.

\section{Reverse transcriptase (RT-PCR)}

Total RNA was extracted using a commercial kit (ISOGEN Nippongene, Toyama, Japan). First-stranded cDNA was synthesized from $1 \mu \mathrm{g}$ total RNA and was subjected to PCR using a RT-PCR kit (Takara, Japan) and PCR system (Gene Amp model 9700). PCR primers for murine RANK were TTAAGCCAGTGCTTCA CGGG (upstream primer) and ACGTAGACCACGAT GATGTCGC (downstream primer), which produced PCR products of $497 \mathrm{bp}$. PCR primers for murine GAPDH were ACCACAGTCCATGCCATCAC (upstream primer) and TCCACCACCCTGTTGCTGTA (downstream primer), which gave PCR products of $452 \mathrm{bp}$. In PCR, annealing was performed at $55^{\circ} \mathrm{C}$ for $30 \mathrm{~s}$ and primer extension was done at $72{ }^{\circ} \mathrm{C}$ for $1 \mathrm{~min}$. After 30 cycles of the reaction, PCR products were separated on a $2 \%$ agarose gel and stained with ethidium bromide. Northern blotting analysis was performed according to a standard protocol. Briefly, total RNA was applied to $1 \cdot 2 \%$ agarose-formaldehyde gel $(10 \mu \mathrm{g} / \mathrm{lane})$ and electrophoresis was performed in $20 \mathrm{mM} 3$-( $N$-morpholino) 
Table 1 Demonstration of four types of RAW264 cell clones

\begin{tabular}{|c|c|c|c|c|c|}
\hline & \multicolumn{2}{|c|}{$\begin{array}{l}\text { TRAP-positive } \\
\text { mononuclear cells }\end{array}$} & \multicolumn{2}{|c|}{ TRAP-positive MNCs } & \multirow[b]{2}{*}{$\begin{array}{l}\text { No. of nuclei } \\
\text { per MNC }\end{array}$} \\
\hline & $\begin{array}{l}\text { Staining } \\
\text { intensity }\end{array}$ & $\begin{array}{l}\text { Percent in total } \\
\text { mononuclear } \\
\text { cells }\end{array}$ & $\begin{array}{l}\text { Staining } \\
\text { intensity }\end{array}$ & $\begin{array}{l}\text { Percent in total } \\
\text { MNCs }\end{array}$ & \\
\hline \multicolumn{6}{|c|}{$\begin{array}{l}\text { Differentiation } \\
\text { phenotype }\end{array}$} \\
\hline i & +++ & 100 & +++ & 100 & $3-100$ \\
\hline II & + & $10-50$ & + & 100 & $3-5$ \\
\hline III & ++ & $20-50$ & - & 0 & - \\
\hline IV & - & 0 & - & 0 & - \\
\hline
\end{tabular}

MNC, multinucleated cell. - , no cells were stained for TRAP; + , cells were weakly stained for TRAP; ++ , cells were moderately stained for TRAP; +++ , cells were strongly stained for TRAP.

propanesulfonic acid (MOPS) buffer $(\mathrm{pH} 7 \cdot 0)$ containing $8 \mathrm{mM}$ sodium acetate and $1 \mathrm{mM}$ EDTA. After gel electrophoresis, RNA was blotted onto the Hybond- $\mathrm{N}^{+}$nylon membrane sheet (Boehringer Mannheim). This sheet was prehybridized in DIG Easy Hyb (Boehringer Mannheim) at $65^{\circ} \mathrm{C}$ for $30 \mathrm{~min}$ and hybridized with DIG-labeled murine cathepsin $\mathrm{K}$ probe at $65^{\circ} \mathrm{C}$ overnight. After washing twice in $2 \times$ SSC containing $0 \cdot 1 \%$ SDS (room temperature, each wash $5 \mathrm{~min}$ ) and twice in $0.5 \times \mathrm{SSC}$ containing $0 \cdot 1 \% \operatorname{SDS}\left(68^{\circ} \mathrm{C}\right.$, each wash $\left.20 \mathrm{~min}\right)$, the membrane was treated with blocking solution for $30 \mathrm{~min}$ at room temprature. The hybridization signal was detected by use of anti-DIG antibody and CDP-star system (Boehringer Mannheim).

\section{Statistical analysis}

The number of TRAP-positive cells was counted and each value was represented as the mean \pm S.E.M. of quadruplicate cultures of 24-multiwell plates. All data obtained from bone marrow cultures were analyzed using Student's $t$-test and a post-ANOVA test.

\section{Results}

Isolation of several types of RAW264 cell clones with different potentials for osteoclastogenesis

In cultures of RAW264 cells, significant heterogeneity of the cell population was noticed when these cells were cultured for the formation of osteoclast-like cells. In these cultures, colonies of TRAP-positive cells were frequently observed (data not shown). This observation strongly suggested the presence of several clones with different potentials for osteoclastogenesis in the conditions stimulated by the differentiation factors. Therefore, we began separating clones with different potentials for osteoclastogenesis from the original RAW264 cells by cloning these cells using a standard limiting dilution technique.
We examined 36 clones with regard to their ability to form osteoclast-like cells. These clones were grouped into four categories with respect to their potential for osteoclastogenesis, as shown in Table 1. The first type of clone (I) efficiently differentiated into multinucleated osteoclastlike cells with numerous nuclei. The second type of clone (II) differentiated into osteoclast-like cells with few nuclei (3-5 nuclei per multinucleated cell (MNC)). The third type of clone (III) differentiated into mononuclear TRAPpositive cells, however, these cells never differentiated into multinucleated cells. In contrast to the above three types of clones, the fourth type of clone (IV) differentiated into neither mononuclear TRAP-positive cells nor multinucleated osteoclast-like cells. We designated one representative clone from the first type as RAW264 cell D (differentiation) clone (D clone) and one representative clone from the fourth type as RAW264 cell N (nondifferentiation) clone ( $\mathrm{N}$ clone). Figure 1 shows the microscopic observation of the D clone when stimulated by various concentrations of RANKL in the presence of $1 \mathrm{ng} / \mathrm{ml}$ TNF- $\alpha$. Although the original RAW264 cells required $100 \mathrm{ng} / \mathrm{ml}$ RANKL to form TRAP-positive MNCs, the D clone was efficiently differentiated into TRAP-positive MNCs at a lower concentration (20 ng/ $\mathrm{ml}$ ) of RANKL. Figure 2 shows a comparison of the differentiation efficiencies among the $\mathrm{D}$ clone, the $\mathrm{N}$ clone, original RAW264 cells and RAW264.7 cells. The D clone showed the highest sensitivity to RANKL, forming numerous TRAP-positive MNCs, even when these cells were cultured in 96-multiwell plates. Although RAW264.7 cells formed TRAP-negative MNCs in response to RANKL, the D clone did not form TRAPnegative MNCs (data not shown). Figure 3 demonstrates the response of the $\mathrm{D}$ clone to TNF- $\alpha$ in the presense of $20 \mathrm{ng} / \mathrm{ml}$ RANKL. TNF- $\alpha$ markedly stimulated osteoclast-like cell formation from the $\mathrm{D}$ clone. To clarify if the D clone expressed characteristics of osteoclast precursors, we examined the effect of calcitonin on the formation of TRAP-positive MNCs. As shown in 


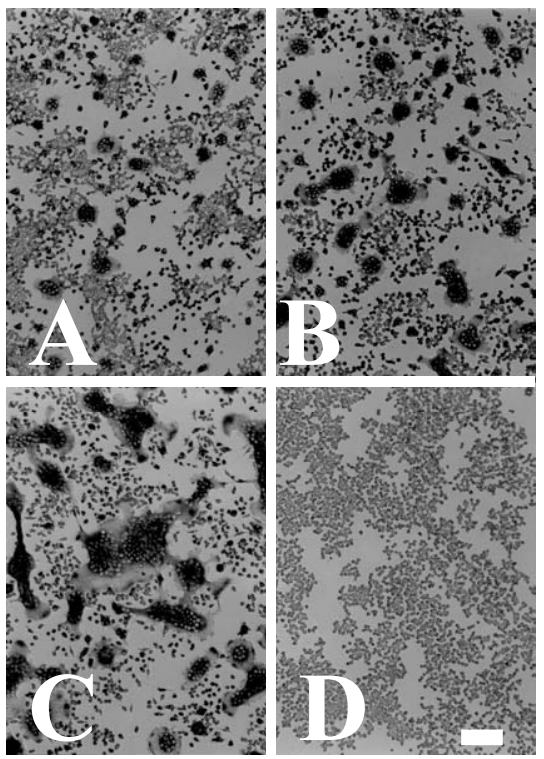

Figure 1 Morphological demonstration of osteoclast-like cells formed from the RAW264 cell D clone. A, B and C: cells of the D clone were cultured in 96-multiwell plates as described in Materials and Methods in the presence of 20,40 and $80 \mathrm{ng} / \mathrm{ml}$ RANKL ( $A, B$ and $C$ respectively). Cells of the D clone efficiently differentiated into TRAP-positive MNCs even at lower concentrations (20 ng/ml) of RANKL (A). Numerous large MNCs were formed from the RAW264 cell D clone at higher concentrations (40 and $80 \mathrm{ng} / \mathrm{ml}$ ) of RANKL (B and C). D: in contrast, the $\mathrm{N}$ clone did not form any TRAP-positive cells even in the presence of $80 \mathrm{ng} / \mathrm{ml}$ RANKL. All these cultures were performed in the presence of $1 \mathrm{ng} / \mathrm{ml}$ TNF- $\alpha$. Scale bar, $100 \mu \mathrm{m}$.

Figure 4, calcitonin significantly suppressed the formation of osteoclast-like MNCs from the D clone. Northern blotting analysis showed that a significant expression of cathepsin $\mathrm{K}$ mRNA was detected in the $\mathrm{D}$ clone when stimulated with RANKL and TNF- $\alpha$, while no expression of this mRNA was detected in the $\mathrm{N}$ clone treated with these cytokines (Fig. 5). We also comfirmed that osteoclast-like MNCs formed from the D clone resorbed dentin (data not shown). We further examined the expression of RANK, the receptor for RANKL, in these clones before they were stimulated with RANKL and TNF- $\alpha$. Semiquantitative RT-PCR analysis showed that both clones (D and $\mathrm{N}$ ) expressed RANK at least by RNA (Fig. 6). These data suggest that the remarkable difference between the $\mathrm{D}$ clone and the $\mathrm{N}$ clone in their potentials for osteoclastogenesis is not a result of differences in RANK expression. These findings demonstrate the usefulness of the $\mathrm{D}$ clone for studies on the molecular mechanisms of osteoclastogenesis.

MIP-1a stimulates formation of preosteoclasts from bone marrow cells deprived of stromal cells

We reported previously that MIP- $1 \alpha$ stimulates osteoclastogenesis in a rat whole bone marrow culture system

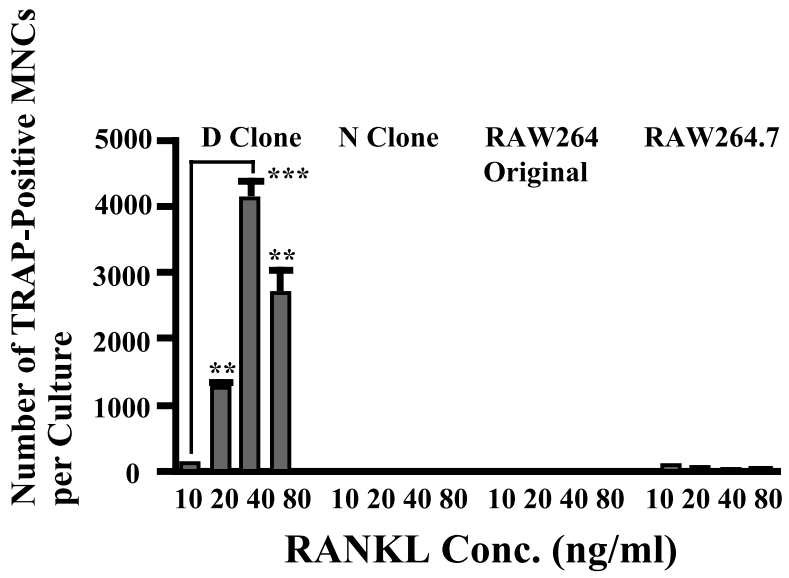

Figure 2 Comparison of the efficiency of osteoclast-like cell formation among various RAW264 cells. The dosage effect of RANKL on osteoclastogenesis was examined among different RAW cells. The D clone, N clone, RAW264 original cells and RAW264.7 cells were cultured in 96-multiwell plates in the presence of $1 \mathrm{ng} / \mathrm{ml}$ TNF- $\alpha$ with various concentrations of RANKL (10-80 ng/ml). In cultures of RAW264 original cells, TRAP-positive mononuclear cells were observed, however, few TRAP-positive MNCs were observed. Numerous TRAP-positive MNCs at greater than 4000 per well were formed from the $\mathrm{D}$ clone. No osteoclast-like cells were formed from the $\mathrm{N}$ clone. Low numbers of osteoclast-like MNCs were formed from RAW264.7 cells. ${ }^{* *} P<0 \cdot 01 ;{ }^{* * *} P<0 \cdot 001$. Data represent a typical experiment for three independent experiments.

containing bone marrow stromal cells. The direct action of MIP- $1 \alpha$ on cells in the osteoclast lineage was assessed by use of rat bone marrow cells deprived of stromal cells. MIP-1 $\alpha$ significantly stimulated formation of TRAPpositive preosteoclast-like mononuclear cells as shown in Fig. 7. Peak stimulation was obtained with $1 \mathrm{ng} / \mathrm{ml}$

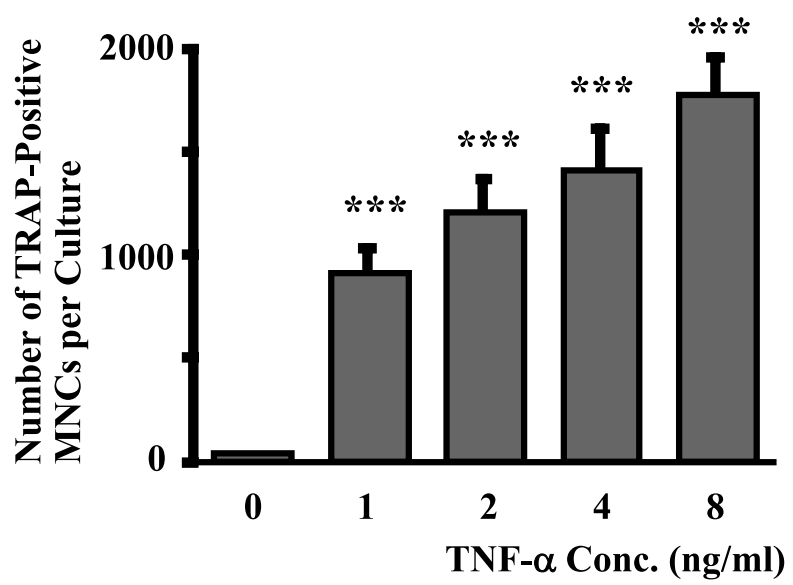

Figure 3 Response of the D clone to TNF- $\alpha$ on the formation of osteoclast-like cells. The D clone was cultured in 96-multiwell plates in the presence of $20 \mathrm{ng} / \mathrm{ml}$ RANKL with various concentrations of TNF- $\alpha$. TNF- $\alpha$ markedly stimulated osteoclast-like cell formation in the presence of RANKL. ${ }^{* *} P<0 \cdot 001$. Data represent a typical experiment for three independent experiments. 


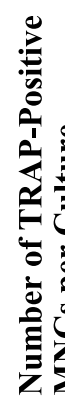

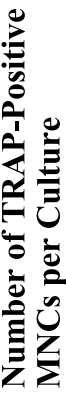

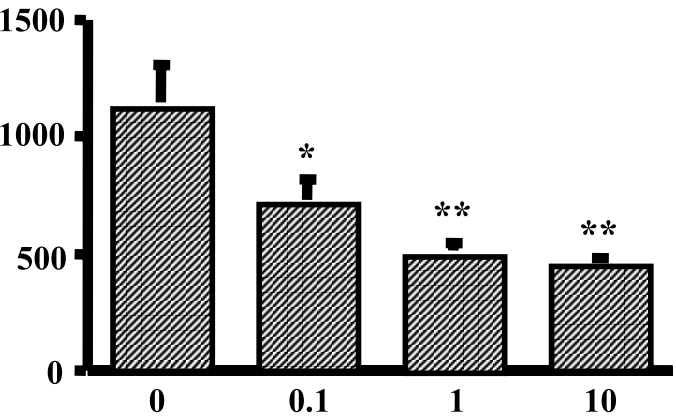

Calcitonin Conc. (ng/ml)

Figure 4 Suppressive effect of salmon calcitonin on the formation of osteoclast-like cells from the D clone. Cells were cultured in 96-multiwell culture plates for forming osteoclast-like MNCs in the presence of $20 \mathrm{ng} / \mathrm{ml}$ RANKL and $1 \mathrm{ng} / \mathrm{ml} \mathrm{TNF}-\alpha$ in the presence of various concentrations of salmon calcitonin. Calcitonin significantly inhibited the formation of TRAP-positive MNCs in a dose-dependent manner. ${ }^{*} P<0 \cdot 05 ;{ }^{*} P<0 \cdot 01$. Data represent a typical experiment for three independent experiments.

MIP- $1 \alpha$ in the presence of $1 \alpha, 25(\mathrm{OH})_{2} \mathrm{D}_{3}$. However, MIP-1 $\alpha$ showed no stimulatory effect in the absence of $1 \alpha, 25(\mathrm{OH})_{2} \mathrm{D}_{3}$. These results strongly suggest that MIP-1 $\alpha$ acts directly on cells in the osteoclast lineage and stimulates the formation of preosteoclasts from bone marrow cells deprived of stromal cells.

MIP-1a stimulates formation of osteoclast-like MNCs from RAW264 cell D clone

To confirm that MIP-1 $\alpha$ acts directly on cells in the osteoclast lineage, we examined the effect of MIP-1 $\alpha$ on

\section{$\begin{array}{lllll}1 & 2 & 3 & 4 & 5\end{array}$ \\ Cathepsin K GAPDH

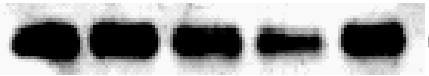

Figure 5 Induction of cathepsin $\mathrm{K}$ mRNA in the D clone but not in the $\mathrm{N}$ clone after being stimulated with factors for osteoclastogenesis. Both the $\mathrm{N}$ clone and the $\mathrm{D}$ clone were stimulated with $20 \mathrm{ng} / \mathrm{ml}$ RANKL and $1 \mathrm{ng} / \mathrm{ml} \mathrm{TNF-} \alpha$ for $48 \mathrm{~h}$; total RNAs were then prepared from these cells. Expression of cathepsin $\mathrm{K}$ was examined by use of Northern blotting analysis as described in Materials and Methods ( $10 \mu \mathrm{g}$ total RNA per lane). Clear induction of cathepsin $\mathrm{K}$ mRNA expression was observed in the $\mathrm{D}$ clone but not in the $\mathrm{N}$ clone. Lane 1, unstimulated $\mathrm{N}$ clone; lane 2, unstimulate $\mathrm{D}$ clone; lane 3 , the $\mathrm{N}$ clone stimulated by RANKL and TNF- $\alpha$; lane 4 , the D clone stimulated by RANKL and TNF- $\alpha$; lane 5 , the D clone stimulated by RANKL, TNF- $\alpha$ and MIP- $1 \alpha(1 \mathrm{ng} / \mathrm{ml})$. The membrane sheet was hybridized with DIG-labeled cathepsin K probe and the same membrane was reprobed with DIG-labeled GAPDH probe.

\section{N- D- clone clone}

\section{RANK GAPDH}
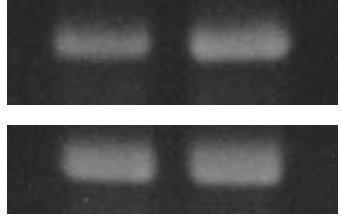

Figure 6 Expression of RANK mRNA in both the $\mathrm{N}$ clone and the D clone, before stimulation with factors for osteoclastogenesis. Cells were cultured in the absence of factors for osteoclastogenesis and total RNAs were prepared from these cells; RANK mRNA expression was then examined using RT-PCR analysis, as described in Materials and Methods. Both the $\mathrm{N}$ clone and the D clone expressed mRNA for RANK.

osteoclastogenesis using RAW264 cell D clone as shown in Fig. 8. MIP-1 $\alpha$ stimulated formation of TRAP-positive MNCs from the D clone when cells were stimulated with RANKL and TNF- $\alpha$, while no MIP- $1 \alpha$-induced osteoclastogenesis was observed in the $\mathrm{N}$ clone, even in the presence of RANKL and TNF- $\alpha$. To establish the optimum concentration of MIP- $1 \alpha$ for osteoclastogenesis from cells of the D clone, we used finer doses of MIP-1 $\alpha$ to assess osteoclastogenic activity. As shown in Table 2,

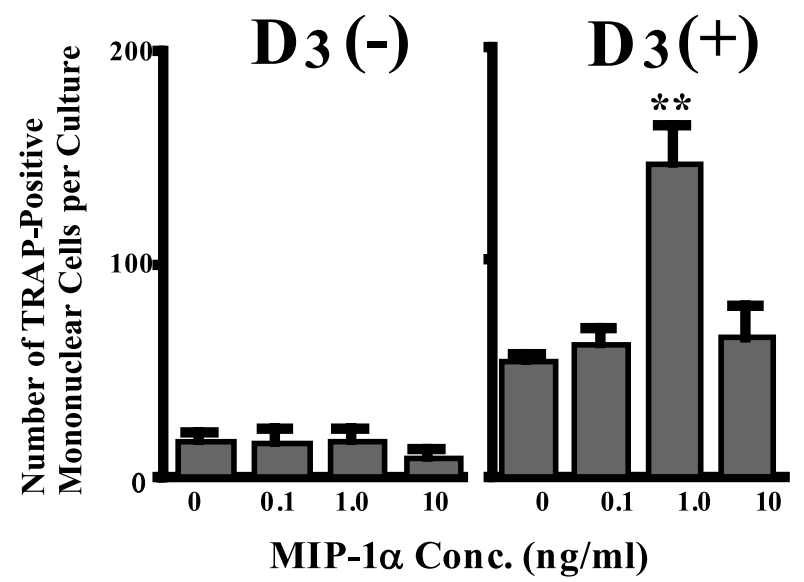

Figure 7 Dosage effect of MIP- $1 \alpha$ on the formation of mononuclear preosteoclast-like cells from rat bone marrow cells deprived of stromal cells. Rat bone marrow cells deprived of stromal cells were cultured in 24-multiwell plates in the presence of various concentrations of MIP- $1 \alpha$ as described in Materials and Methods. MIP-1 $\alpha$ significantly stimulated the formation of preosteoclast-like mononuclear cells in the presence of $10^{-8} \mathrm{M}$ $1 \alpha, 25(\mathrm{OH})_{2} \mathrm{D}_{3}$ (right panel, $\left.\mathrm{D}_{3}\left({ }^{+}\right)\right)$but not in the absence of $1 \alpha, 25(\mathrm{OH})_{2} \mathrm{D}_{3}$ (left panel, $\mathrm{D}_{3}(-)$ ). Peak stimulation was observed at $1 \mathrm{ng} / \mathrm{ml} \mathrm{MIP-1 \alpha .}{ }^{* *} P<0 \cdot 01$. Data represent a typical experiment for three independent experiments. 


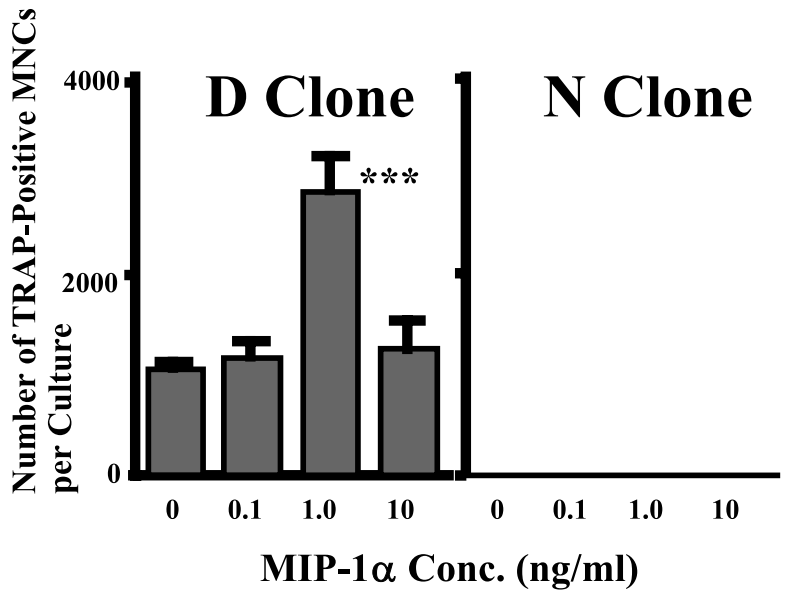

Figure 8 Dosage effect of MIP- $1 \alpha$ on the formation of osteoclast-like MNCs from cells of the D clone and the $\mathrm{N}$ clone. Cells were cultured for forming osteoclast-like cells in the presence of $20 \mathrm{ng} / \mathrm{ml}$ RANKL and $1 \mathrm{ng} / \mathrm{ml}$ TNF- $\alpha$ with various concentrations of MIP-1 $\alpha$. A marked stimulation of osteoclastogenesis was observed in the presence of $1 \mathrm{ng} / \mathrm{ml}$ MIP- $1 \alpha$ in the D clone (left panel), while no induction of osteoclastogenesis was observed in the $\mathrm{N}$ clone (right panel). ${ }^{* * *} P<0 \cdot 001$. Data represent a typical experiment for four independent experiments.

maximal stimulation was observed at $1-2 \mathrm{ng} / \mathrm{ml}$ MIP-1 $\alpha$. We further examined whether the type II clone responded to MIP-1 $\alpha$. Osteoclastogenesis was also significantly stimulated by $2-6 \mathrm{ng} / \mathrm{ml}$ MIP-1 $\alpha$ in the type II RAW264 clone (Table 3). These results provide strong evidence to show that MIP-1 $\alpha$ acts directly on cells in the osteoclast lineage to stimulate osteoclastogenesis. We also confirmed the cathepsin K mRNA expression formed in osteoclast-

Table 2 Dosage effects of MIP- $1 \alpha$ on the formation of osteoclast-like MNCs from cells of the D clone

\section{No. of TRAP-positive MNCs per culture (mean \pm S.E.M.)}

Level of significance

\section{MIP-1 $\alpha$ concentration} $(\mathrm{ng} / \mathrm{ml})$

$\begin{array}{lrl}0 & 664 \cdot 0 & \pm 130 \cdot 5 \\ 0 \cdot 25 & 989 \cdot 3 \pm 164 \cdot 0 & \\ 0 \cdot 5 & 1600 \cdot 5 \pm 120 \cdot 6 & * * P<0 \cdot 01 \\ 1 & 1987 \cdot 5 \pm 109 \cdot 7 & * * P<0 \cdot 01 \\ 2 & 2171 \cdot 8 \pm 154 \cdot 2 & * * P<0 \cdot 01 \\ 4 & 1918 \cdot 0 \pm 258 \cdot 3 & * P<0 \cdot 05\end{array}$

Cells of the D clone were cultured in 96-multiwell plates to form osteoclast-like MNCs $\left(4.5 \times 10^{4}\right.$ cells $/ \mathrm{ml}, 150 \mu \mathrm{l} /$ well $)$ in the presence of $20 \mathrm{ng} / \mathrm{ml}$ RANKL and $1 \mathrm{ng} / \mathrm{ml}$ TNF- $\alpha$. Various concentrations of MIP- $1 \alpha$ were added. MIP-1 $\alpha(0.5-4 \mathrm{ng} / \mathrm{ml})$ significantly stimulated formation of TRAP-positive MNCs in a dose-dependent manner $* P<0 \cdot 05 * * * P<0 \cdot 01$ Data represent a typical experiment for three independent experiments.
Table 3 MIP- $1 \alpha$ stimulation of osteoclastogenesis from cells of type II clone RAW264 cells

\begin{tabular}{|c|c|c|}
\hline & $\begin{array}{l}\text { No. of TRAP-positive } \\
\text { MNCs per culture } \\
\text { (mean } \pm \text { S.E.M.) }\end{array}$ & $\begin{array}{l}\text { Level of } \\
\text { significance }\end{array}$ \\
\hline \multicolumn{3}{|c|}{$\begin{array}{l}\text { MIP-1 } \alpha \text { concentration } \\
(\mathrm{ng} / \mathrm{ml})\end{array}$} \\
\hline 0 & $9 \cdot 25 \pm 1 \cdot 18$ & \\
\hline $0 \cdot 25$ & $13 \cdot 25 \pm 1 \cdot 18$ & \\
\hline $0 \cdot 5$ & $17 \cdot 25 \pm 3 \cdot 92$ & \\
\hline 1 & $17 \cdot 25 \pm 5 \cdot 18$ & \\
\hline 2 & $22 \cdot 75 \pm 4 \cdot 38$ & ${ }^{*} P<0.05$ \\
\hline 4 & $23.5 \pm 3.66$ & ${ }^{*} P<0.05$ \\
\hline 6 & $21 \cdot 25 \pm 3 \cdot 61$ & ${ }^{\star} P<0.05$ \\
\hline 8 & $14 \cdot 25 \pm 2 \cdot 78$ & \\
\hline 10 & $14 \cdot 0 \pm 2 \cdot 54$ & \\
\hline
\end{tabular}

Cells of type II clone were cultured in 96-multiwell plates $\left(4.5 \times 10^{4}\right.$ cells $/ \mathrm{ml}$, $150 \mu \mathrm{l} /$ well) to form osteoclast-like MNCs in the presence of $20 \mathrm{ng} / \mathrm{ml}$ RANKL and $1 \mathrm{ng} / \mathrm{ml}$ TNF- $\alpha$. Various concentrations of MIP- $1 \alpha$ were added. MIP- $1 \alpha$ significantly stimulated the formation of TRAP-positive MNCs at concentrations of $2-6 \mathrm{ng} / \mathrm{ml}$. ${ }^{*} P<0 \cdot 05$. Data represent a typical experiment for three independent experiments.

like cells in the presence of MIP-1 $\alpha$, as shown in Fig. 5 (lane 5).

MIP-1a stimulates fusion among osteoclast-like MNCs formed from the $\mathrm{D}$ clone

MIP-1 $\alpha$ markedly stimulated the formation of osteoclastlike MNCs (Fig. 8), however, higher concentrations of MIP-1 $\alpha$ tended to suppress the number of MNCs formed in these cultures. This apparently suppressive effect of high doses of MIP-1 $\alpha$ could be attributed to stimulation of fusion among osteoclast-like MNCs. Therefore, we examined this possibility by creating a histogram in which the relation between MIP- $1 \alpha$ dose and the degree of multinucleation was assessed, as shown in Fig. 9. Higher concentrations of MIP- $1 \alpha$ significantly stimulated formation of MNCs with a large number of nuclei of greater than 41 nuclei per osteoclast-like MNC. These findings strongly suggest that the apparent decrease in the number of osteoclast-like MNCs formed in the presence of $10 \mathrm{ng} /$ $\mathrm{ml}$ of MIP-1 $\alpha$ (Fig. 8) is a result of stimulation of fusion in osteoclast-like MNCs.

\section{MIP-1a-induced adhesion of the D clone to primary osteoblasts}

The adhesion of osteoclast precursors to osteoblasts is an important step in the regulation of osteoclastogenesis. Therefore, we further investigated whether MIP-1 $\alpha$ modulates the adhesion properties of the $\mathrm{D}$ clone to primary osteoblasts. As shown in Fig. 10, the MIP-1 $\alpha$ treated D clone adhered efficiently to primary osteoblasts in comparison with untreated D clones. These results 


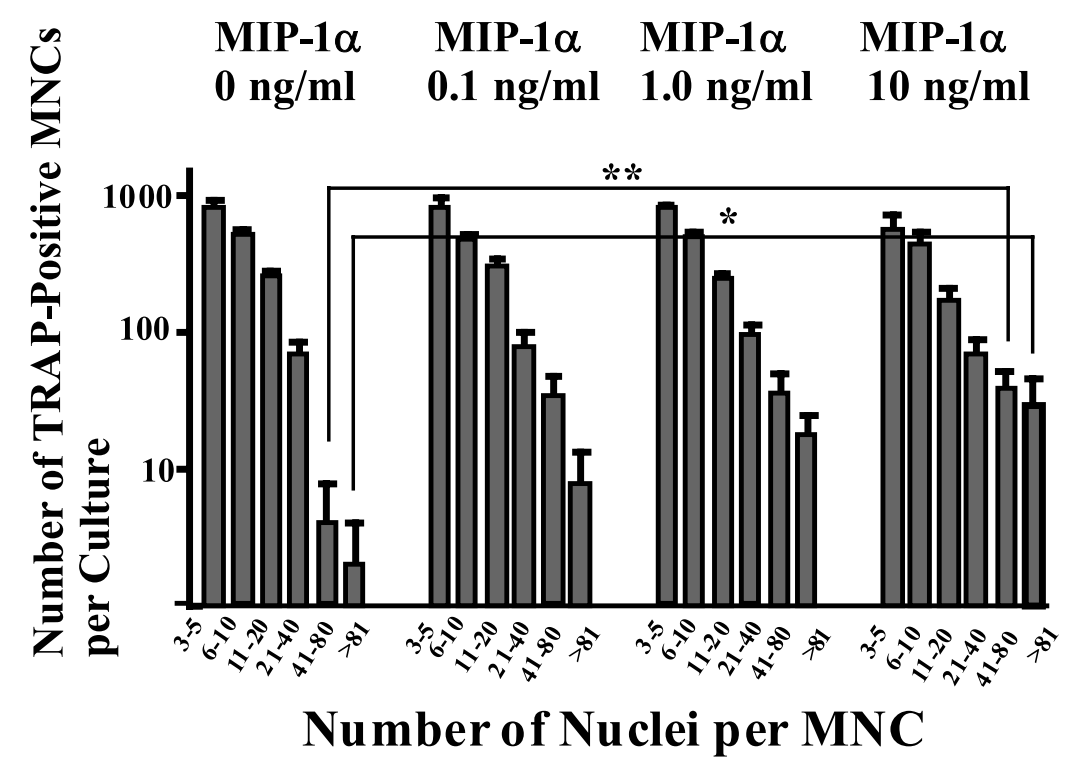

Figure 9 Dosage effect of MIP- $1 \alpha$ on the nuclear number of formed osteoclast-like MNCs. Cells of the D clone were cultured in 96-multiwell plates for forming osteoclast-like MNCs in the presence of $20 \mathrm{ng} / \mathrm{ml} \mathrm{RANKL}$ and $1 \mathrm{ng} / \mathrm{ml} \mathrm{TNF}-\alpha$ with various concentrations of MIP- $1 \alpha$. After staining for TRAP, 16 fields $(12 \cdot 6 \%$ of the total area of each well) were randomly selected from each well and the numbers of osteoclast-like MNCs with different ranges of nuclear number were separately counted. The Figure shows the number of MNCs in each nuclear number range. At higher concentrations of MIP- $1 \alpha$, the numbers of MNCs with numerous nuclei (greater than 41 nuclei per $\mathrm{MNC}$ ) was markedly increased. ${ }^{*} P<0 \cdot 05,{ }^{*} P<0 \cdot 01$. Data represent a typical experiment for three independent experiments.

suggest that MIP-1 $\alpha$ induces expression of adhesion molecules on the cell surface of the D clone. Previously, we reported that lymphocyte function-associated antigen-1 (LFA1) is expressed on mononuclear precursors of rat osteoclasts and that this molecule participates in the regulation of osteoclastogenesis (Harada et al. 1998). Therefore, expression of LFA $1 \alpha$ and $\beta$ on the surface of the $\mathrm{D}$ clones was examined by use of specific antibodies. Both molecules were expressed on the cell surface of the D clone, however, the level of the expression was not altered when these cells were treated with MIP-1 $\alpha$ (data not shown).

\section{Discussion}

The macrophage-like cell line RAW264 is useful for studying osteoclastogenesis. The $\mathrm{D}$ clone used in the present study, is able to differentiate into osteoclast-like MNCs at a very high rate even at low concentrations of RANKL, while the $\mathrm{N}$ clone has no ability to differentiate into osteoclast-like cells. Although these two types of clones were derived from the same origin, sensitivity to RANKL differed between these clones. We also obtained other types of clones that had intermediate potentials for osteoclastogenesis. One type of clone differentiated into TRAP-positive MNCs, however, their number of nuclei was limited to 3-5 per cell. Another type of clone differentiated into mononuclear TRAP-positive preosteoclast-like cells, but they never fused to each other to form MNCs. These four types of RAW264 cell clones are suggested to be suitable for molecular analysis of osteoclastogenesis involving signal transduction studies. They will be of value for studies of the molecular mechanisms of osteoclast differentiation, to isolate and maintain stable RAW264 cell clones with different responses against differentiation stimuli. RT-PCR analysis and Northern blotting analysis showed that both the D clone and the $\mathrm{N}$ clone expressed significant levels of RANK, the receptor for RANKL, but that only the D clone expressed cathepsin $\mathrm{K}$ after being stimulated for osteoclastogenesis. Anderson et al. (1997) stated that RANK mRNA levels do not accurately predict RANK protein expression on the cell surface. It is true that there is a limitation of using RANK mRNA to predict RANKL responsiveness and the potentiation of the MIP-1 $\alpha$ signal; further analysis is required in respect of the RANK protein expression on the cell surface of RAW264 cell clones. However, the current data may suggest that the $\mathrm{N}$ clone has some defects in the signaling pathway, downstream of RANK, that leads to the expression of molecules required for osteoclastogenesis. The D clone, $\mathrm{N}$ clone and other 


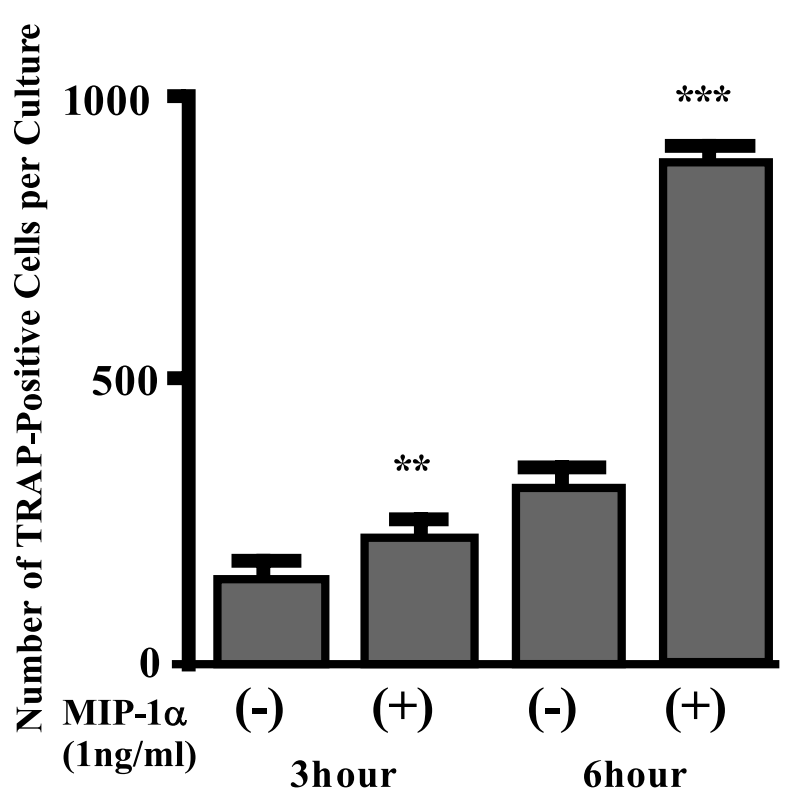

Figure 10 Induction of osteoblast adhesion in the $\mathrm{D}$ clone by treatment with MIP-1 $\alpha$. Primary osteoblasts were obtained and cultured to be confluent as described in Materials and Methods. The D clone was cultured for 2 days in the presence of $20 \mathrm{ng} / \mathrm{ml}$ RANKL and $1 \mathrm{ng} / \mathrm{ml} \mathrm{TNF-} \alpha$ with or without $1 \mathrm{ng} / \mathrm{ml}$ of MIP- $1 \alpha$; it was then washed and replated on the monolayers of primary osteoblasts. After 3 and $6 \mathrm{~h}$ incubation in the absence of MIP- $1 \alpha$, non-adherent cells were removed by rinsing in $\alpha$-MEM followed by staining for TRAP. The number of adherent TRAP-positive cells were counted. Marked stimulation of cell adhesion was induced by a treatment of the $\mathrm{D}$ clone with $1 \mathrm{ng} / \mathrm{ml} \mathrm{MIP}-1 \alpha .{ }^{* *} P<0 \cdot 01$, ${ }^{* * *} P<0 \cdot 001$. Data represent a typical experiment for three independent experiments.

clones obtained in this study would provide powerful tools for molecular biological analysis of osteoclast differentiation.

We have previously reported that MIP- $1 \alpha$ participates in osteoclast formation in rat whole bone marrow cultures (Kukita et al. 1992, 1997). We have also reported that MIP- $1 \alpha$ is expressed in human osteoblasts and that this chemokine induces osteoclast formation on dentin slices. However it has not yet been clear whether MIP- $1 \alpha$ acts directly on cells in the osteoclast lineage or not. The current study demonstrates that MIP- $1 \alpha$ acted directly on cells in the osteoclast lineage and induced differentiation in culture systems in which other types of cells were not involved. One of the culture systems used was the stromal cell-deprived bone marrow culture system for forming mononuclear preosteoclast-like cells. The other culture system used was the pure culture system in which only a particular RAW264 cell clone was involved. As MIP-1 $\alpha$ showed stimulation of osteoclastogenesis in both culture systems, it is concluded that MIP- $1 \alpha$ directly acts on cells in the osteoclast lineage to augment formation of osteoclast-like cells. Han et al. (2001) recently reported that CC-chemokine receptor (CCR1) and CCR5 are involved in MIP-1 $\alpha$-induced osteoclastogenesis in culture systems of bone marrow cells from patients with multiple myeloma. In our culture systems for osteoclastogenesis induced by MIP-1 $\alpha$, these chemokine receptors are supposed to play an important role in the stimulation of osteoclastogenesis. Our culture system using the D clone would provide a suitable system for investigating signal transduction mediated by MIP-1 $\alpha$ in osteoclastogenesis. In osteoclast differentiation induced by RANKL, signal transduction through TNF receptor-associated factor 6 (TRAF6) is important (Kobayashi et al. 2001). As stimulation of osteoclastogenesis by MIP-1 $\alpha$ was only observed when cells were treated with RANKL, it is supposed that MIP-1 $\alpha$ could modulate the TRAF6 signaling pathway triggered by RANKL. These studies are underway in our laboratories.

Adhesion of osteoclast progenitors to osteoblasts has been recognized as an essential step for osteoclastogenesis (Takahashi et al. 1988, Tanaka et al. 1998b). Here it has been demonstrated that MIP-1 $\alpha$ dramatically enhances adhesion of the $\mathrm{D}$ clone to the monolayer of primary osteoblasts. The differentiated D clone expressed significant levels of LFA- $1 \alpha$ and $\beta$, however, the level of the expression of these molecules was not altered by the addition of MIP-1 $\alpha$ (data not shown). We can not rule out the possibility that MIP- $1 \alpha$ activates an inactive-form of LFA-1 integrin (Pruijt et al. 1998, Tanaka et al. 1998a, Fibbe et al. 1999) into an active form and that such activation of LFA-1 induces a marked increase in adhesion of the $\mathrm{D}$ clone to osteoblasts. Intercellular adhesion molecule-1 (ICAM-1), the ligand for LFA-1 integrin is known to be expressed on the cell surface of osteoblasts (Kurachi et al. 1993), therefore, activation of LFA-1 on the cell surface of the D clone may result in a marked increase in the cell adhesion of the $\mathrm{D}$ clone to the monolayer of the osteoblasts. Alternatively, we can not rule out the possibility that expression of other cell adhesion molecules was induced by treatment of the D clone with MIP- $1 \alpha$. Further studies are required to elucidate the mechanism explaining the marked stimulation of the adhesion between MIP-1 $\alpha$-treated RAW264 cell D clone and osteoblasts. It is thought that MIP- $1 \alpha$ produced by the osteoblasts acts as a chemotactic factor against osteoclast progenitor cells at an early step of osteoclastogenesis through CCR1 or CCR5. This process is thought to involve activation of some integrin, e.g. LFA1. Activated LFA1 could bind to ICAM-1 expressed on the cell surface of osteoblasts. Such interactions would facilitate the tight adhesion of osteoclast progenitors to osteoblasts, allowing these progenitors to be effectively exposed to RANKL and MIP-1 $\alpha$ produced by osteoblasts. Thus osteoclast progenitors accumulated on the cell surface of osteoblasts would differentiate into real osteoclast precursors. At the subsequent fusion process, MIP-1 $\alpha$ produced by osteoblasts will act to augment cell fusion. Thus it is supposed that MIP- $1 \alpha$ acts as the upregulator of osteoclastogenesis in bone. 
The use of a combination of RAW264 cell clones with different potentials for osteoclastogenesis could provide a powerful tool for clarifying the genes and their products that are essential for each stage of the osteoclast differentiation. This work is now underway in our laboratories.

\section{Acknowledgements}

We thank Dr H Harada of the Faculty of Medical Science, Kyushu University for discussion.

This work was partly supported by a Grant for Scientific Research from the Japanese Ministry of Education, Science and Culture (project 12671775).

\section{References}

Anderson DM, Maraskovsky E, Billingsley WL, Dougall WC, Tometsko ME, Roux ER, Teepe MC, DuBose RF, Cosman D \& Galibert L 1997 A homologue of the TNF receptor and its ligand enhance T-cell growth and dendritic-cell function. Nature $\mathbf{3 9 0}$ $175-179$.

Broxmeyer HE, Sherry B, Cooper S, Lu L, Maze R, Beckmann MP, Cerami A \& Ralph P 1993 Comparative analysis of the human macrophage inflammatory protein family of cytokines (chemokines) on proliferation of human myeloid progenitor cells. Journal of Immunology 150 3448-3458.

Choi SJ, Cruz JC, Craig F, Chung H, Davlin RD, Roodman GD \& Alsina M 2000 Macrophage inflammatory protein 1-alpha is a potential osteoclast stimulatory factor in multiple myeloma. Blood 96 671-675.

Cook DN, Beck MA, Coffman TM, Kirby SL, Sheridan JF, Pragnell IB \& Smithies O 1995 Requirement of MIP-1 alpha for an inflammatory response to viral infection. Science 269 1583-1585.

Fibbe WE, Pruijt JF, Velders GA, Opdenakker G, van Kooyk Y, Figdor CG \& Willemze R 1999 Biology of IL-8-induced stem cell mobilization. Annals of the New York Academy of Sciences 872 71-82.

Han JH, Choi SJ, Kurihara N, Koide M, Oba Y \& Roodman GD 2001 Macrophage inflammatory protein-1 alpha is an osteoclastogenic factor in myeloma that is independent of receptor activator of nuclear factor kappaB ligand. Blood 97 3349-3353.

Harada H, Kukita T, Kukita A, Iwamoto Y \& Iijima T 1998 Involvement of lymphocyte function-associated antigen-1 and intercellular adhesion molecule-1 in osteoclastogenesis: a possible role in direct interaction between osteoclast precursors. Endocrinology 139 3967-3975.

Hsu H, Lacey DL, Dunstan CR, Solovyev I, Colombero A, Timms E, Tan HL, Elliott G, Kelley MJ, Sarosi I, Wang L, Xia XZ, Elliot R, Chiu L, Black T, Scully S, Capparelli C, Morony S, Shimamoto G, Bass MB \& Boyle WJ 1999 Tumor necrosis factor receptor family member RANK mediates osteoclast differentiation and activation induced by osteoprotegerin ligand. PNAS 96 3540-3545.

Inngjerdingen M, Damaj B \& Maghazachi AA 2001 Expression and regulation of chemokine receptors in human natural killer cells. Blood 97 367-375.

Kobayashi N, Kadono Y, Naito A, Matsumoto K, Yamamoto T, Tanaka S \& Inoue J 2001 Segregation of TRAF6-mediated signaling pathways clarifies its role in osteoclastogenesis. EMBO Journal 20 1271-1280.
Kukita A, Kukita T, Hata K, Kurisu K \& Kohashi O 1993a Heat-treated osteoblastic cell (ROS17/2.8)-conditioned medium induces the formation of osteoclast-like cells. Bone and Mineral 23 113-127.

Kukita A, Kukita T, Shin JH \& Kohashi O 19936 Induction of mononuclear precursor cells with osteoclastic phenotypes in a rat bone marrow culture system depleted of stromal cells. Biochemical and Biophysical Research Communications 196 1383-1389.

Kukita T, Nakao J, Hamada F, Kukita A, Inai T, Kurisu K \& Nomiyama H 1992 Recombinant LD78 protein, a member of the small cytokine family, enhances osteoclast differentiation in rat bone marrow culture system. Bone and Mineral 19 215-223

Kukita T, Nomiyama H, Ohmoto Y, Kukita A, Shuto T, Hotokebuchi T, Sugioka Y, Miura R \& Iijima T 1997 Macrophage inflammatory protein-1 alpha (LD78) expressed in human bone marrow: its role in regulation of hematopoiesis and osteoclast recruitment. Laboratory Investigation 76 399-406.

Kurachi T, Morita I \& Murota S 1993 Involvement of adhesion molecules LFA-1 and ICAM-1 in osteoclast development. Biochimica et Biophysica Acta 1178 259-266.

Lukacs NW, Standiford TJ, Chensue SW, Kunkel RG, Strieter RM \& Kunkel SL 1996 C-C chemokine-induced eosinophil chemotaxis during allergic airway inflammation. Journal of Lenkocyte Biology $\mathbf{6 0}$ 573-578.

McDyer JF, Dybul M, Goletz TJ, Kinter AL, Thomas EK, Berzofsky JA, Fauci AS \& Seder RA 1999 Differential effects of CD40 ligand/trimer stimulation on the ability of dendritic cells to replicate and transmit HIV infection: evidence for CC-chemokinedependent and-independent mechanisms. Journal of Immunology 162 $3711-3717$

Nakao M, Nomiyama H \& Shimada K 1990 Structures of human genes coding for cytokine LD78 and their expression. Molecular and Cellular Biology 10 3646-3658.

Neote K, DiGregorio D, Mak JY, Horuk R \& Schall TJ 1993 Molecular cloning, functional expression, and signaling characteristics of a C-C chemokine receptor. Cell 72 415-425.

Pruijt JF, van Kooyk Y, Figdor CG, Lindley IJ, Willemze R \& Fibbe WE 1998 Anti-LFA-1 blocking antibodies prevent mobilization of hematopoietic progenitor cells induced by interleukin-8. Blood 91 4099-4105

Shimada T, Matsumoto M, Tatsumi Y, Kanamaru A \& Akira S 1998 A novel lipopolysaccharide inducible $\mathrm{C}-\mathrm{C}$ chemokine receptor related gene in murine macrophages. FEBS Letters 425 490-494.

Shiozaki H, Ide T, Nakao J, Imamura T, Nakamura M, Shimada K, Miura Y \& Suda T 1992 Suppressive effect of LD78 on the proliferation of human hemopoietic progenitors. Japanese Journal of Cancer Research 83 499-504.

Takahashi N, Akatsu T, Udagawa N, Sasaki T, Yamaguchi A, Moseley JM, Martin TJ \& Suda T 1988 Osteoblastic cells are involved in osteoclast formation. Endocrinology 123 2600-2602.

Tanaka Y, Mine S, Figdor CG, Wake A, Hirano H, Tsukada J, Aso M, Fujii K, Saito K, van Kooyk Y \& Eto S 1998a Constitutive chemokine production results in activation of leukocyte function-associated antigen-1 on adult T-Cell leukemia cells. Blood 91 3909-3919.

Tanaka Y, Mine S, Hanagiri T, Hiraga T, Morimoto I, Figdor CG, van Kooyk Y, Ozawa H, Nakamura T, Yasumoto K \& Eto $\mathrm{S}$ $1998 b$ Constitutive up-regulation of integrin-mediated adhesion of tumor-infiltrating lymphocytes to osteoblasts and bone marrow-derived stromal cells. Cancer Research 58 4138-4145.

Received 16 September 2003

Accepted 3 October 2003 